\section{Australian Journal of \\ Crop Science}

AJCS 15(04):564-569 (2021)

doi: 10.21475/ajcs.21.15.04.p2873

\title{
Planting recommendations for yacon (Smallanthus sonchifolius) in lowland conditions
}

\section{Mateus Augusto Lima Quaresma ${ }^{1}$, Fábio Luiz de Oliveira ${ }^{1}$, Leonardo $\mathrm{F} \mathrm{Rocha}{ }^{2}$, Ariany das Graças Teixeira* ${ }^{1}$, Diego Mathias Natal da Silva ${ }^{1}$, Leandro Pin Dalvi, Marcelo Antonio Tomaz}

\author{
${ }^{1}$ Department of Agronomy, Center of Agricultural Sciences and Engineering, Universidade Federal do Espírito Santo, \\ Alegre-ES, Brazil \\ ${ }^{2}$ Departament of Plant, Soil and Agricultural Systems, Southern Illinois University, Carbondale-IL, United States of \\ America
}

\section{*Corresponding author: arianyteixeira@yahoo.com.br}

\begin{abstract}
The purpose of this work was to test yacon planting practices in low elevation conditions. The experimental design was a randomized block design (RBD) with subdivided plots and four replications. Treatments comprised of three planting methods: furrow; ridges and pits; each treatment was divided into subplots, which were four planting depths: 5, 10, 15, and $20 \mathrm{~cm}$. The following variables were tested: sprouting speed, vigorous sprouting rate, average time for sprouting, rhizophore mortality rate, soil temperature and moisture, shoot dry weight, and yield of rhizophores, tuberous roots, total yield, and marketable tuberous roots. The planting methods using pits and furrows had lower seedling mortality rates $(30,2$ and $41,4 \%$ compared to ridges), while furrow led to a higher total tuber yield (17,5 and 18,9\% higher than ridges and pits), using depths of 5 and $10 \mathrm{~cm}$. The system with pits also achieved significant yields at $10 \mathrm{~cm}$ depth. Using ridges as the planting method would be possible, at depths of 10 and 15 $\mathrm{cm}$, but yields would be lowered. For the conditions of this study, the highest yield of marketable roots was obtained using furrow at 5 and $10 \mathrm{~cm}$ of panting depth.
\end{abstract}

Keywords: Smallanthus sonchifolius; Polymnia sonchifolia; diet potato; production system. Abbreviations: RBD_randomized block design; DAP_days after planting; GT_green tip; OB_open bud; AST_average sprouting time; SRI_sprouting rate index; FSR_final sprouting rate; VSR_vigorous sprouting rate; MR_mortality rate.

\section{Introduction}

Worldwide demand for functional foods is rising for various factors, including their nutraceutical properties, which are described as bioactive compounds offering health benefits (Sacramento et al., 2017). These compounds include inulin, fructooligosaccharides (FOS), and their derivatives (Sumiyanto et al., 2012).

The ongoing trend of adopting non-typical vegetables with nutraceutical properties, combined with the increased demand of these products by both the pharmaceutical and food industry, spotlight plants originated in South America, such as the tweedie's catsear (Hypochaeri schillensis), arrowroot (Maranta arundinacea) and yacon (Smallanthus sonchifolius). These plants are great candidates to deliver raw materials to the pharma and food industries (Hauly and Moscatto, 2002; Magalhães, 2017).

Yacon is included in this group of functional foods for the presence of bioactive (inulin and FOS) and phenolic compounds, such as chlorogenic acid, ferulic and caffeic acid, and flavonoids such as quercetin (Ojansivu et al., 2011). This crop is produced from low (close to sea level) to very high altitudes (from 1000 to 3400 meters), with substantial fluctuations in yield (Vitali et al., 2015), which highlights the demand for improved crop management practices. Due to the increase in the demand for yacon, better cropping practices, such as optimized planting recommendations, are demanded for different edaphoclimatic conditions where this crop is being established (Silva et al., 2018a; Vanini et al., 2009).

Defining optimal planting techniques is essential considering their influence on plant development and yield, as previously detailed for potatoes by Martini et al. (1990); for Peruvian carrot (Arracacia xanthorriza Bancroft.) by Gomes et al. (2010); for peanuts by Grotta et al. (2008) and others. Planting method and depth directly affect seedling emergence and initial development, affecting crop performance and yield. These interactions are, in most situations, linked to the temperature and moisture variation in distinct soil layers, and likewise to soil physical restrictions for seedling germination (Dantas et al., 2020; Pequeno et al., 2007; Agbede, 2010). Planting conditions also interfere in the requirement for water and nutrients and root interactions with macro and microorganisms (Taiz and Zeiger, 2013).

The first report of yacon production in Brazil, conducted by Kakihara et al. (1996), already exposed the scarcity of crop management recommendations. Vilhena et al. (2000) proposed using planting beds measuring $1 \mathrm{~m}$ wide and 0.30 $\mathrm{m}$ height for yacon production in Brazil, diverging with 
planting techniques adopted in the Andean region where the crop is planted in furrows (Seminario et al, 2003).

These deviations in planting recommendations for yacon show the demand for enhanced crop management practices. The aim of this work was to assess different planting methods and depths, and their effect on crop development and yield of tuberous roots, under low elevation conditions.

\section{Results and discussion}

\section{Vegetative stage evaluations}

The planting method influenced average sprouting time (AST), with the best AST observed when the crop was planted in ridges, reflecting in lower average sprouting time (Table 1).

The vigorous sprouting rate (VSR) showed variation due to planting depths for only one method. When using ridges, the highest VSR was observed with depths of 10 and $15 \mathrm{~cm}$. For furrows and pits, there was no VSR variation due to planting depths (Table 1).

For furrow planting, depths of 5 to $15 \mathrm{~cm}$ led to lower seedling mortality rates. When the method of planting in pits was chosen, the smallest seedling mortality values were noted at $10 \mathrm{~cm}$. For ridges, the lowest mortality rates occurred from 10 to $20 \mathrm{~cm}$, implying that using lower depths $(5 \mathrm{~cm})$ increased seedling mortality rate in this approach (Table 1).

These results illustrate a demand for an adjustment in planting depth for each method, to provide optimal emergence conditions. These planting recommendations combined with optimal soil temperature and moisture will be the major drivers of the initial yacon establishment.

The ridges method promoted the least vigorous sprouting rate and highest seedling mortality, regardless of the planting depth (Table 1). This result may be a consequence of higher soil temperatures (Fig 1.) and lower soil moisture (Fig 2.), registered for this system during the crop cycle. This variation led to the larger mortality rate noted for this approach when rhizophores were grown in shallower layers $(5 \mathrm{~cm})$.

The results again highlight the effect of planting methods in the relation between temperature and soil moisture. When using ridges as a planting method, due to increased soil solarization and temperature increment, the speed of bud sprouting was boosted, resulting in a smaller average sprouting time compared to other approaches. Temperature and soil moisture play a considerable role in controlling several physiological processes connected to budding and/or the emergence of most plant species (Taiz and Zeiger, 2013). However, increases in soil temperature favor water evaporation and water loss, which would rise the mortality rate of the seedlings, as observed for sugarcane (Carvalho et al., 2012) and corn (Cortez et al., 2015).

\section{Production and yield of yacon}

When evaluating the plant development via plant dry weight, the highest readings for shoots in the furrow system were observed for planting depths of 5 to $10 \mathrm{~cm}$. The ridges method led to a higher dry weight at $10 \mathrm{~cm}$, whereas no planting depth effects were observed when using pits. Similar results were observed for the dry weight of rhizophores (Table 2).

The dry weight of tuberous roots was higher when using planting depths of 5 and $10 \mathrm{~cm}$ in furrows. For both ridge and pit methods, higher dry weight was noted at depths of $10 \mathrm{~cm}$ (Table 2).

Furrow promoted higher dry weight of shoots and tuberous roots, regardless of planting depths (Table 2), pointing out this approach as the most suitable for the development and production of yacon roots under lowland cropping conditions.

The greatest yield of tuberous roots using furrows was registered at depths of 5 and $10 \mathrm{~cm}$. For both ridges and pits, the highest yields were obtained when planting at depths of $10 \mathrm{~cm}$ (Table 3).

In the case of marketable roots, the highest yields were reported at depths of 5 and $10 \mathrm{~cm}$ for both furrows and pits. For ridges, higher yields were observed at 10 and $15 \mathrm{~cm}$ (Table 3).

These results propose that, for each planting system, an optimal depth is recommended to maximize the yacon yield. These divergences are due to their interference on key soil conditions for crop development, such as lower thermal amplitudes and higher soil moisture, as noticed in the crop establishment stage. Optimal environmental conditions may display not simply in more robust plant growth but as well in greater yields (Rós et al., 2014; Silva et al., 2018b).

Using furrow as the planting method, regardless of planting depths, promoted higher yields of total and commercial yacon tuberous roots (Table 3 ), possibly pertained to further beneficial conditions for crop growth, such as lower thermal amplitude and higher moisture content in the soil, which are optimal conditions for yacon production (Silva et al., 2018b). Under lowland conditions in the Itapemirim river valley, the furrow planting method promotes higher yields, especially at depths of 5 and $10 \mathrm{~cm}$. The pit method also produces significant yields at $10 \mathrm{~cm}$ depth. Using ridges as the planting program would be conceivable, with depths of 10 and 15 $\mathrm{cm}$, but not justified due to reduced yields.

\section{Materials and methods}

\section{Experimental area}

Field trials were conducted in 2015 in the CCAE-UFES Research Farm, in Rive, a village of Alegre, in Southern Espírito Santo state, Brazil. The field geographical coordinates are $20^{\circ} 46^{\prime} 2.8^{\prime \prime} \mathrm{S}$ and $41^{\circ} 27^{\prime} 39.2^{\prime \prime} \mathrm{W}$, with $128 \mathrm{~m}$ of elevation. This zone, which is in the Itapemirim river valley, is classified as a hot tropical micro-region (lowlands) (Pezzopane et al., 2012). The highest monthly temperatures vary from 26.5 to $31.4^{\circ} \mathrm{C}$, and the lowest from 19.5 to $23.1^{\circ}$ C, with $514 \mathrm{~mm}$ of accumulative rainfall during field experiments (INMET, 2015).

\section{Soil description and analysis}

The field plot design adopted for this experiment was utilized for vegetable production and left under fallow for four months before the beginning of field trials. Plots were mowed using a handle trimmer and after a week; soil was plowed to a depth of $20 \mathrm{~cm}$ and disked twice, incorporating weed in the topsoil layer.

The soil in the experimental plot was classified as red-yellow oxisol, medium texture (Santos et al., 2013). Chemical and physical analysis were conducted, resulting in the following for the $0-20 \mathrm{~cm}$ layer: $\mathrm{pH}: 6.89$ (water); $\mathrm{P}: 80.34 \mathrm{mg} \mathrm{dm}^{-3}$ (Mehlich); K: $227.00 \mathrm{mg} \mathrm{dm}^{-3}$; Ca: $3.29 \mathrm{cmolc} \mathrm{dm}^{-3}$; Mg: 1.83 cmolc dm${ }^{-3}$; Al: $0.05 \mathrm{cmolc} \mathrm{dm}^{-3} ; \mathrm{H}+\mathrm{Al}: 1.15 \mathrm{cmolc} \mathrm{dm}^{-3}$; BS: $5.93 \mathrm{cmolc} \mathrm{dm}^{-3}$; t: $5.95 \mathrm{cmolc} \mathrm{dm}^{-3}$; T: $7.08 \mathrm{cmolc} \mathrm{dm}^{-3}$; V: 78.39\%; sand: $56 \%$, silt: $33 \%$ and clay: $11 \%$. 
Table 1. Sprouting speed, the average time for sprouting, vigorous sprouting rate, and rhizophore mortality rate in yacon with different planting methods. Alegre - ES, 2015.

\begin{tabular}{|c|c|c|c|c|c|c|}
\hline & \multicolumn{6}{|c|}{ Planting Method } \\
\hline & Furrows & Ridges & Pits & Furrows & Ridges & Pits \\
\hline & \multicolumn{3}{|c|}{ Sprouting rate index (buds/day) } & \multicolumn{3}{|c|}{ Average sprouting time (days) } \\
\hline Mean & $1.45 \mathrm{~B}^{1}$ & $1.63 \mathrm{~A}$ & $1.47 \mathrm{~B}$ & $65.84 \mathrm{~A}$ & $56.51 \mathrm{~B}$ & $66.81 \mathrm{~A}$ \\
\hline $\mathrm{CV}$ & 18.62 & & & 19.16 & & \\
\hline Depth & \multicolumn{3}{|c|}{ Vigorous Sprouting Rate (\%) } & \multicolumn{3}{|c|}{ Mortality Rate (\%) } \\
\hline $5 \mathrm{~cm}$ & $78.85 a^{2}$ & $57.20 \mathrm{~b}$ & $78.68 \mathrm{a}$ & $5.9 \mathrm{~b}$ & $16.7 \mathrm{a}$ & $8.8 \mathrm{a}$ \\
\hline $10 \mathrm{~cm}$ & $83.95 \mathrm{a}$ & $75.14 \mathrm{a}$ & $88.32 \mathrm{a}$ & $5.7 \mathrm{~b}$ & $11.2 \mathrm{~b}$ & $6.9 \mathrm{~b}$ \\
\hline $15 \mathrm{~cm}$ & $74.94 \mathrm{a}$ & $66.78 \mathrm{ab}$ & $85.48 \mathrm{a}$ & $7.1 \mathrm{ab}$ & $8.3 \mathrm{~b}$ & $7.2 \mathrm{a}$ \\
\hline $20 \mathrm{~cm}$ & $82.20 \mathrm{a}$ & $55.83 \mathrm{~b}$ & $74.66 \mathrm{a}$ & $9.5 \mathrm{a}$ & $11.9 \mathrm{~b}$ & $10.7 \mathrm{a}$ \\
\hline Mean & $79.98 A^{1}$ & $63.74 \mathrm{~B}$ & $81.78 \mathrm{~A}$ & $7.05 \mathrm{~B}$ & $12.03 \mathrm{~A}$ & $8.40 \mathrm{~B}$ \\
\hline
\end{tabular}

${ }^{1}$ Means related to planting methods independent of depths. Means followed by the same upper case in the same row and lower case do not differ by Tukey's test at a $5 \%$ probability level. ${ }^{2}$ Means followed by the same lower case in the same column do not differ by Tukey's test at a $5 \%$ probability level

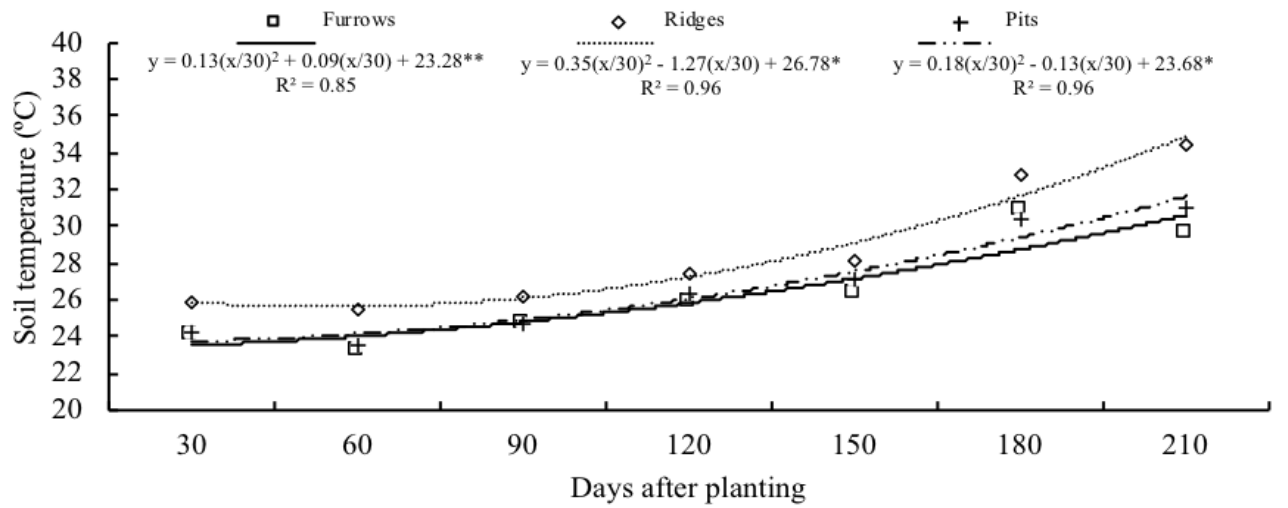

Fig 1. Soil temperature in the $0-20 \mathrm{~cm}$ layer in a yacon crop area with different planting methods. Alegre $-E S, 2015 .{ }^{*} \mathrm{P} \leq 0.01 ; * * P \leq 0.05$.

Table 2. Dry weight of shoots, rhizophores, and tuber roots of yacon plants with different methods and depth of planting. Alegre - ES, 2015. Depth Planting Method

\begin{tabular}{|c|c|c|c|c|c|c|}
\hline \multirow[t]{3}{*}{ Depth } & \multicolumn{6}{|c|}{ Planting Method } \\
\hline & Furrows & Ridges & Pits & Furrows & Ridges & Pits \\
\hline & \multicolumn{3}{|c|}{ Shoot dry weight (t ha ${ }^{-1}$ ) } & \multicolumn{3}{|c|}{ Rhizophores dry weight $\left(\mathrm{t} \mathrm{ha}^{-1}\right)$} \\
\hline $5 \mathrm{~cm}$ & $2.10 a^{1}$ & $1.45 \mathrm{~b}$ & $1.43 \mathrm{a}$ & $2.34 \mathrm{ab}$ & $1.78 \mathrm{~b}$ & $2.19 \mathrm{a}$ \\
\hline $10 \mathrm{~cm}$ & $2.02 a b$ & $1.88 \mathrm{a}$ & $1.42 \mathrm{a}$ & $2.46 \mathrm{a}$ & $2.38 \mathrm{a}$ & $1.92 \mathrm{a}$ \\
\hline $15 \mathrm{~cm}$ & $1.61 \mathrm{bc}$ & $1.58 \mathrm{~b}$ & $1.56 \mathrm{a}$ & $1.99 \mathrm{bc}$ & $2.45 \mathrm{a}$ & $2.07 \mathrm{a}$ \\
\hline $20 \mathrm{~cm}$ & $1.29 \mathrm{c}$ & $1.47 \mathrm{~b}$ & $1.49 \mathrm{a}$ & $1.76 \mathrm{c}$ & $1.77 \mathrm{~b}$ & $2.34 \mathrm{a}$ \\
\hline Mean & $1.75 \mathrm{~A}^{2}$ & $1.59 \mathrm{~B}$ & $1.48 \mathrm{C}$ & $2.14 \mathrm{~A}$ & $2.10 \mathrm{~A}$ & $2.13 \mathrm{~A}$ \\
\hline $\mathrm{CV}$ & 14.25 & & & 10.90 & & \\
\hline \multirow[t]{2}{*}{ Depth } & Furrows & & Ridges & & Pits & \\
\hline & \multicolumn{6}{|c|}{ Tuber dry weight $\left(\mathrm{t} \mathrm{ha}^{-1}\right)$} \\
\hline $5 \mathrm{~cm}$ & $4.49 \mathrm{a}^{1}$ & & $2.49 \mathrm{~b}$ & & $3.04 \mathrm{~b}$ & \\
\hline $10 \mathrm{~cm}$ & $4.78 \mathrm{a}$ & & $3.62 \mathrm{a}$ & & $3.86 \mathrm{a}$ & \\
\hline $15 \mathrm{~cm}$ & $3.28 \mathrm{~b}$ & & $2.94 \mathrm{~b}$ & & $2.36 \mathrm{c}$ & \\
\hline $20 \mathrm{~cm}$ & $1.65 \mathrm{c}$ & & $2.64 \mathrm{~b}$ & & $2.30 \mathrm{c}$ & \\
\hline Mean & $3.55 A^{2}$ & & $2.92 \mathrm{~B}$ & & $2.89 \mathrm{~B}$ & \\
\hline $\mathrm{CV}$ & 10.08 & & & & & \\
\hline
\end{tabular}

${ }^{1}$ Means followed by the same lower case in the same column do not differ by Tukey's test at a $5 \%$ probability level. ${ }^{2}$ Means related to planting methods independent of depths. Means followed by the same upper case in the same row and lower case do not differ by Tukey's test at a $5 \%$ probability level.

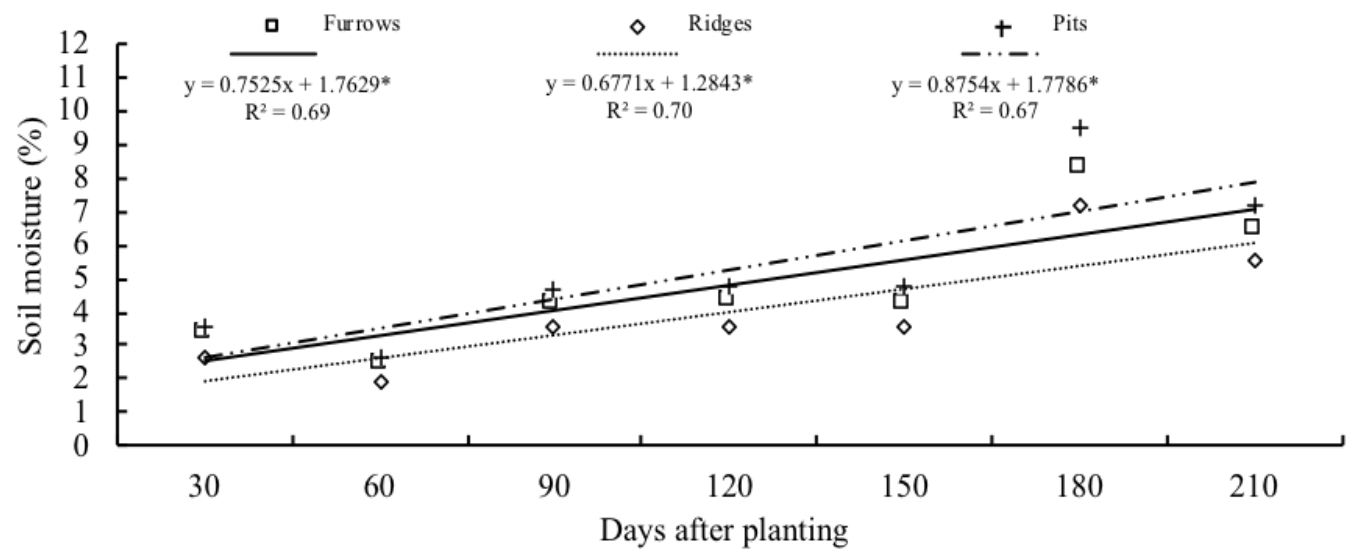

Fig 2. Soil moisture in the $0-20 \mathrm{~cm}$ layer in a yacon crop area with different planting methods. Alegre $-E S, 2015{ }^{*} \mathrm{P} \leq 0.01 ; * * \mathrm{P} \leq 0.05$. 
Table 3. Marketable and total (unmarketable + marketable) tuber yield of yacon plants with different methods and depth of planting. Alegre - ES, 2015

\begin{tabular}{|c|c|c|c|c|c|c|}
\hline \multirow[t]{3}{*}{ Depth } & \multicolumn{6}{|c|}{ Planting Methods } \\
\hline & Furrows & Ridges & Pits & Furrows & Ridges & Pits \\
\hline & \multicolumn{3}{|c|}{ Total tuber yield $\left(\mathrm{t} \mathrm{ha}^{-1}\right)$} & \multicolumn{3}{|c|}{ Marketable tuber yield $\left(\mathrm{t} \mathrm{ha}^{-1}\right)$} \\
\hline $5 \mathrm{~cm}$ & $49.16 \mathrm{a}^{1}$ & $26.62 \mathrm{~b}$ & $32.04 \mathrm{~b}$ & $33.25 \mathrm{a}$ & $17.29 \mathrm{~b}$ & $23.29 \mathrm{a}$ \\
\hline $10 \mathrm{~cm}$ & $50.21 \mathrm{a}$ & $39.21 \mathrm{a}$ & $41.02 \mathrm{a}$ & $33.33 \mathrm{a}$ & $26.58 \mathrm{a}$ & $27.97 \mathrm{a}$ \\
\hline $15 \mathrm{~cm}$ & $35.08 b$ & $31.21 b$ & $25.06 \mathrm{c}$ & $25.66 \mathrm{~b}$ & $23.50 \mathrm{ab}$ & $13.87 \mathrm{~b}$ \\
\hline $20 \mathrm{~cm}$ & $17.80 \mathrm{c}$ & $28.54 \mathrm{~b}$ & $24.79 \mathrm{c}$ & $10.16 \mathrm{c}$ & $19.08 \mathrm{~b}$ & $13.71 \mathrm{~b}$ \\
\hline Mean & $38.06 \mathrm{~A}^{2}$ & $31.39 \mathrm{~B}$ & $30.87 \mathrm{~B}$ & $25.60 \mathrm{~A}$ & $21.61 \mathrm{~B}$ & $19.71 \mathrm{~B}$ \\
\hline $\mathrm{CV}$ & 10.53 & & & 16.30 & & \\
\hline
\end{tabular}

${ }^{1}$ Means followed by the same lower case in the same column do not differ by Tukey's test at a $5 \%$ probability level. ${ }^{2}$ Means related to planting methods independent of depths. Means followed by the same upper case in the same row and lower case do not differ by Tukey's test at a $5 \%$ probability level.

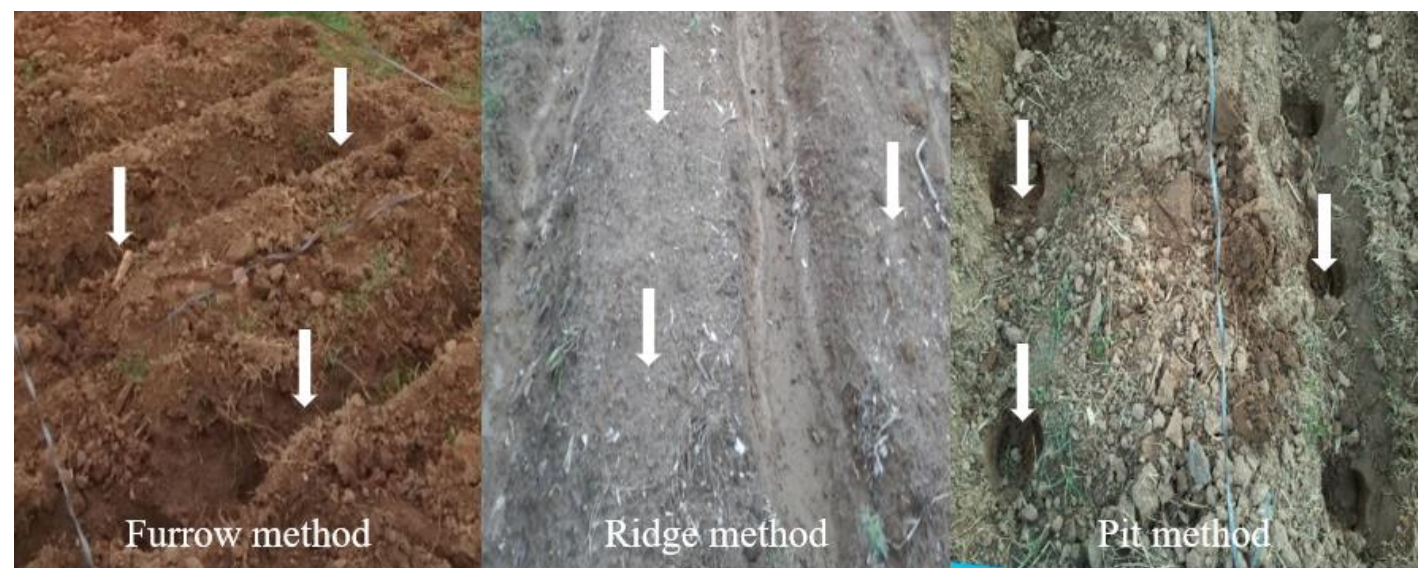

Fig 3. Sketch of planting methods, the arrows indicate the planting location for Smallanthus sonchifolius crop. Alegre - ES, 2015. Photo: Quaresma MAL

\section{Yacon planting and crop management}

Yacon rhizophores, collected from a production field in the city of Santa Maria do Jetibá (Espírito Santo state, Brazil), were adopted as propagative materials. The rhizophores were collected three days before planting. Rhizophores were selected and fractionated in 40-50 g portions and afterward cleaned using water followed by a solution of sodium hypochlorite solution $(5 \% \mathrm{v} / \mathrm{v})$ for 10 minutes. After treatment, rhizophores were dried for two days in a ventilated and shaded space.

The fertilizer recommendation was based on the work by Amaya Robles (2000). Composted cow manure was applied in doses of $170 \mathrm{~g}$ at planting and $750 \mathrm{~g}$ in a subsequent application, which was conducted 90 days after planting. This amount was comparable to $104.37 \mathrm{~kg} \mathrm{ha}^{-1}$ of nitrogen, based on manure nutrient levels $(1.67 \% \mathrm{~N} 2,0.59 \% \mathrm{~K} 2 \mathrm{O}$, and $0.38 \%$ P2O5). Yacon was planted in late April, recognized to be the most productive season, conforming to the work by Silva et al. (2018a), studying yacon in the same region.

Weeds were managed between rows bi-weekly using a string trimmer up to four months after planting and weed biomass was left protecting the soil. A sprinkler system was utilized for supplementary irrigations, adding $110 \mathrm{~mm}$ to the present rainfall $(520 \mathrm{~mm})$ during the crop period, amounting to $600 \mathrm{~mm}$, which is the demand for yacon crop, according to Grau and Rea (1997).

\section{Experimental design}

The experimental design was a randomized block design (RBD) with subdivided plots and four replications. Treatments included three planting methods: furrows, ridges and pits (Fig 3.); subplots were four planting depths: 5, 10, 15 , and $20 \mathrm{~cm}$.

Planting furrows were concave, shaped with an opening of $20 \mathrm{~cm}$ wide by $20 \mathrm{~cm}$ deep. Ridges were convex, with a base of $50 \mathrm{~cm}$ wide and $40 \mathrm{~cm}$ high (both built using gardening hoes). The pit radius measured $10 \mathrm{~cm}$ with a depth of $20 \mathrm{~cm}$ (built using soil diggers).

Each experimental subplot was constituted of 28 plants, enclosing a section of $11.2 \mathrm{~m} 2(3.5 \times 3.2 \mathrm{~m})$, providing 10 plants for evaluation, totaling 600 tested plants from 1680 grown in $672 \mathrm{~m} 2$. The distance between rows was $0.8 \mathrm{~m}$ and $0.5 \mathrm{~m}$ between plants, producing a plant population of $25,000 \mathrm{ha}^{-1}$. These planting instructions are based on the work by Seminario et al. (2003), recommending higher plant populations.

\section{Evaluations}

The following parameters were tested: sprouting speed, vigor sprouting rate, the average time for sprouting, rhizophore mortality rate, soil temperature and moisture in the $0-20 \mathrm{~cm}$ layer, shoot dry weight, and yield of rhizophores, tuberous roots, total yield, and marketable tuberous roots.

Initial assessments were performed every 15 days, always at the same time $(8 \mathrm{~h}), 75$ days after planting (DAP). The evaluation method followed Maguire (1962), according to the vegetative stages "Green Tip" (GT), which is described as the appearance of modifications in the coloring of the gems, with a greenish tip, and "Open Bud" (OB). Based on these vegetative stages, the following variables were calculated. Average sprouting time (AST): average number of days spent between experiment beginning on each date and detecting the vegetative stages "Green Tip" (GT) (appearance of modifications in the coloration of the buds, with the greenish tip);

Sprouting rate index (SRI): occurrence of sprouting buds due to the sprouting time given the equation:

$S R=S\left(\frac{n i}{t i}\right)($ buds per day) 
Where:

ni = number of buds that reached the GT stage at time "i"; $\mathrm{ti}=$ time in days after the test setup ( $\mathrm{i}=1$ to 45$)$.

Final sprouting rate (FSR): percentage of rhizophores sections with buds that reached the GT stage;

Vigorous Sprouting Rate (VSR): percentage of rhizophores sections with buds in the GT stage that progressed to the "Open Bud" (OP) stage (open leaf appearance). In the analyzed period, given by the equation:

\section{VSR $=(\%$ of rhizophores section with GT stages $) \times 100$}

Mortality rate (MR): percentage of rhizophores sections that remained alive and vigorous until the end of the evaluations. Soil temperature was checked from 30 to 210 DAP, between plants within planting rows, at depths of $0-20 \mathrm{~cm}$, from 2:00 and 3:00 p.m. The readings were collected in real-time using a digital thermometer attached to a metal probe (SoloTerm 1200; SOLOTEST, São Paulo, SP, Brazil). Soil moisture (volumetric) was measured between 10:00 and 11:00 a.m., between plants within planting rows, in the same soil layer, and dates used for temperature. The moisture data were collected using an electronic reader (HidroFarm; Falker, Porto Alegre, RS, Brazil), supporting direct volumetric moisture measuring.

The dry weight for each plant part was obtained after drying samples in the oven with forced air circulation at 65을 continuous weight was reached. Dried plant material was weighed on a digital scale, with an accuracy of $0.01 \mathrm{~g}$. Tuberous roots were classified as commercial when equal or greater than the ideal for fresh consumption, consisting of roots from 10 to $20 \mathrm{~cm}$, with 120 to $300 \mathrm{~g}$ of weight (Oliveira, 2016).

\section{Statistical analysis}

Using the Shapiro-Wilk test, means were initially tested assuming residue normality and later assuming homogeneity among variances using Bartlett's test. For data suggesting the existence of a functional relationship between two variables over time, regression tests were conducted, and the polynomial quadratic equation best fit these data relationships were determined. Additional data were contrasted using the Tukey test. All statistical analyses ( $t$ and F) used $p<0.05$.

\section{Conclusions}

The highest yields of yacon tuberous roots under lowland conditions were achieved with the furrow system, at depths of 5 and $10 \mathrm{~cm}$ of planting.

\section{Acknowledgments}

The authors acknowledge CNPq and FAPES for supporting this research project. FAPES provided the doctoral scholarship and research support for the first author and the scholarship "Capixaba Researcher" for the second author.

\section{References}

Agbede TM (2010) Tillage and fertilizer effects on some soil properties, leaf nutrient concentrations, growth, and sweet potato yield on an Alfisol in southwestern Nigeria. Soil Till Res. 110:25-32.
Amaya Robles JE (2000) Efeitos de doses crescentes de nitrogênio e potássio na produtividade de Yacon (Polymnia sonchifolia Poep. \& Endl.) (master's thesis). Paulista State University, Botucatu, Brazil.

Carvalho LA, Meurer I, Silva Júnior CA, Centurion JF (2012) Spatial variability of soil physical properties in two management systems in sugarcane crop. Eng Agríc. 32:6068.

Cortez JW, Nagahama HJ, Olszevski N, Patrocinio Filho AP, de Souza EB (2015) Umidade e temperatura de argissolo amarelo em sistemas de preparo e estádios de desenvolvimento do milho. Eng Agríc. 35:699-710.

Dantas BF, Moura MSB, Pelacani CR, Angelotti F, Taura TA, Oliveira GM, Bispo JS, Matias JR, Silva FFS, Pritchard HW, Seal CE (2020) Rainfall, not soil temperature, will limit the seed germination of dry forest species with climate change. Oecologia. 192:529-541.

Gomes HE, Heredia Zárate NA, Vieira MC, Gassi RP, Torales EP, Macedo RV (2010) Produção de mudas e de raízes comerciais de mandioquinha-salsa 'Amarela de Carandai' em função de espaçamentos e amontoa. Semina Ciênc Agrár. 31:1121-1132.

Grau A, Rea J (1997) Genetic resources of yacon Smallanthus sonchifolius Poepp. \& Endl. In: Heller J, Hermman M, Engels J. Andean roots and tuber genetic resources. IPGRI, Rome.

Grotta DCC, Furlani CEA, Silva RP, Reis GN, Cortez JW, Alves PJ (2008) Influência da profundidade de semeadura e da compactação do solo sobre a semente na produtividade do amendoim. Ciênc Agrotec. 32:547-552.

Hauly MCO, Moscatto JA (2002) Inulina e oligofrutose: uma revisão sobre propriedades funcionais, efeito prebiótico e importância na indústria de alimentos. Semin Ciênc exatas tecnol. 2:105-118.

INMET - Instituto Nacional de Meteorologia do Brasil - online database. Available in $<$ http://www.inmet.gov.br/portal/index.php?r=bdmep/bd mep> Accessed in December of 2017

Kakihara TS, Câmara FLA, Vilhena SMC, Riera L (1996) Cultivo e industrialização de yacon (Polymnia sonchifolia): uma experiência brasileira. In: Latin American Congress of Tropical Roots 1 and Brazilian Congress of Cassava 9, UNESP, Brazil.

Magalhães R (2017) Regulação de alimentos no brasil. Rev Direito Sanit. 17:113-133.

Maguire JD (1962) Speed of germination - aid in selection and evaluation for seedling emergence and vigor. Crop Sci. 2:176-177.

Martini LCP, Konig O, Franke, A (1990) Influência da amontoa e da adubação de cobertura na produção e qualidade da batata (Solanum tuberosum L). Rev Centro de Ciências Rurais. 20:247-254.

Ojansivu I, Ferreira CL, Salminen S (2011) Yacon, a new source of prebiotic oligosaccharides with a history of safe use. Trends Food Sci Tech. 22:40-46.

Oliveira T (2016) Classificação de batata yacon na CEAGESP. Boletim do Centro de Qualidade, Pesquisa \& Desenvolvimento da CEAGESP, São Paulo.

Pequeno MG, Vidigal Filho PS, Tormena C, Kvitschal MV, Manzotti M (2007) Efeito do sistema de preparo do solo sobre características agronômicas da mandioca (Manihot esculenta Crantz). R Bras Eng Agríc Ambiental. 11:476-481.

Pezzopane JEM, Castro FS, Pezzopane JRM, Cecílio RA (2012) Agrometeorologia: aplicações para o Espírito Santo. CAUFES, Alegre. 
Rós AB, Tavares Filho JE, Barbosa GMC (2014) Propriedades físicas de solo em diferentes sistemas de preparo para o cultivo da batata-doce. Semina Ciênc Agrár. 35:227-238.

Sacramento MS, Da Silva PSRC, Tavares MIB (2017) Batata yacon-alimento funcional. R Semioses. 11:43-48.

Santos HG, Jacomine PKT, Anjos LHC, Oliveira VA, Lumbreras JF, Coelho MR, Almeida JA, Cunha TJF, Oliveira JB (2013) Sistema brasileira de classificação de solos. Embrapa, Brasília.

Seminario J, Valderrama M, Manrique I (2003) El yacon: fundamentos para el aprovechamiento de un recurso promisorio. Centro International de la Papa (CIP), Universidad Nacional de Cajamarca, Agencia Suiza para el Desarrollo y la Cooperación (COSUDE), Lima.

Silva DMN, Oliveira FL, Cavatte PC, Quaresma MAL, Christo BF (2018a) Growth and development of yacon in different periods of planting and growing conditions. Acta Sci Agron. 40:1-9.
Silva DMN, Venturim CHP, Valory Capucho MEO, Oliveira FL, Mendonça ES (2018b) Impact of soil cover systems on soil quality and organic production of yacon. Sci Hort. 235:407412.

Sumiyanto J, Dayan FE, Cerdeira AL, Wang $Y$, Khan IA, Moraes RM (2012) Oligofructans content and yield of Yacon (Smallanthus sonchifolius) cultivated in Mississipi. Sci Hort. 148:83-88.

Taiz L, Zeiger E (2013) Fisiologia Vegetal. 5. ed. Artemed, Porto Alegre.

Vilhena SMC, Câmara FA, Kakihara ST (2000) O cultivo de yacon no Brasil. Hortic Bras. 18:5-8.

Vanini M, Barbieri RL, Ceolin T, Heck RM, Mesquita MK (2009) A relação do tubérculo andino yacon com a saúde humana. Ciênc Cuid Saúde. 8:92-96.

Vitali MS, Sancho G, Katinas L (2015) A revision of Smallanthus (Asteraceae, Millerieae), the "yacón" genus. Phytotaxa. 214:1-84. 